Univerzita Mateja Bela

v Banskej Bystrici

pavol.odalos@umb.sk

\title{
TRADÍCIA A DYNAMIKA ONOMASTICKEJ TERMINOLÓGIE A TERMINOLÓGIA ONOMASTICKÝCH ŠKÔL
}

Kl'úč o vé s lová: onomastická terminológia — terminológia onomastických škôl

\section{ÚVODNÁ POZNÁMKA}

Zámerom príspevku je predstavit’ na základe tradície a dynamiky slovenskej a slovanskej onomastickej terminológie vrátane terminológie slovanských onomastických škôl podnety k d'alšiemu rozvoju sústavy slovenskej a slovanskej onomastickej terminológie.

\section{TRADÍCIA ONOMASTICKEJ TERMINOLÓGIE}

\subsection{Sústava onomastickej terminológie}

Sústava slovenskej a slovanskej onomastickej terminológie bola venovaná VII. medzinárodnému zjazdu slavistov a vyšla v roku 1973 pod názvom Základná sústava a terminológia slovanskej onomastiky (Svoboda a kol. 1973). Impulzom k jej vzniku bol IV. medzinárodný zjazd slavistov v roku 1958 v Moskve, kde bolo navrhnuté, aby sa zjednotila a normovala slovanská jazykovedná terminológia, a I. slavistická onomastická konferencia v roku 1959 v Krakove, kde bol prijatý návrh, aby sa v nadväznosti na jazykovednú terminológiu začala vytvárat’ aj slovanská onomastická terminológia.

Základná sústava a terminológia slovanskej onomastiky (d’alej Základná sústava terminológie) bola rozdelená do dvoch častí. V prvej časti, ktorá bola pomenovaná ako A, sa nachádzali onomastické termíny podl'a objektov a javov označovaných vlastnými menami. V druhej časti, ktorá bola pomenovaná ako $\mathrm{B}$, sa nachádzali termíny opisu a spracovania vlastných mien. V časti A bolo 47 termínov a v časti B 175 termínov, spolu 222 termínov v slovenskej sústave onomastickej terminológie.

Onomastické termíny podl'a objektov a javov označených vlastnými menami sú rozdelené do dvoch skupín na 1 . bionymy a 2 . abionymy. Dôvod zmeny výcho- 
diskovej kriteriálnej dvojice zo Svobodovho súpisu názov veci oproti vlastnému menu živých tvorov na bionymum oproti abionymum nie je v odbornej literatúre $\mathrm{v}$ rámci správ o prácach na terminológii známy a v odbornej literatúre zachytený. Na základe ústnej informácie R. Šrámka ho navrhol E. Eichler a podporil V. Blanár. Zmena východiskovej klasifikačnej dvojice na bionymum — abionymum znamená iný výber zo základných kategórií skutočnosti, pretože východiskom sa stala kategória l’udí, ktorá je základom civilizácie homo sapiens sapiens.

Bionymum je vlastné meno živého organizmu alebo organizmu, ktorý si človek predstavil ako živý. Bionymum ako nadradený termín zastrešuje: 1.1. antroponymum s významom vlastné meno jednotlivého človeka alebo skupiny l'udí, 1.2. nepravé antroponymum s významom vlastné meno bytosti, ktorú si človek predstavoval ako l'ud’om podobnú, 1.3. zoonymum s významom vlastné meno živočícha (domáceho, v zoologickej záhrade a pod.), 1.4. nepravé zoonymum s významom vlastné meno živočícha, ktorý fakticky neexistoval/neexistuje, teda živočícha mytologického, rozprávkového či vystupujúceho v bájkach, 1.5. fytonymum s významom vlastné meno rastliny.

Antroponymum sa následne delí na 1.1.1. osobné meno s významom vlastné meno jednotlivého človeka, 1.1.2. skupinové antroponymum s významom vlastné meno skupiny l'udí, ktorá tvorí isté spoločenstvo.

Osobné meno sa člení na mužské vlastné meno, chlapčenské vlastné meno, ženské vlastné meno, dievčenské vlastné meno, osobné vlastné meno v jednomennej sústave, rodné/krstné meno, prímeno, šl'achtický prídomok, priezvisko, živé rodinné meno/meno podla domu. Skupinové antroponymum sa rozčleňuje na rodové meno, obyvatel'ské meno, etnické meno/etnonymum. Pri nepravých antroponymách sa ešte uvádza teonymum čiže osobné meno boha.

Bionymická čast' obsahuje 27 termínov (22 terminologických pojmov).

Abionymum je chápané ako vlastné meno neživého objektu a javu prírodného alebo človekom vytvoreného. Abionymum zastrešuje 2.1. toponymum s významom vlastné meno neživého prírodného objektu a javu a toho človekom vytvoreného objektu, ktorý je v krajine pevne fixovaný a 2.2. chrématonymum $\mathrm{s}$ významom vlastné meno l'udského výtvoru, ktorý nie je pevne fixovaný v prírode $\mathrm{v}$ zmysle vlastného meno spoločenského javu, spoločenskej inštitúcie, jednotlivého alebo sériového predmetu a výrobku.

Toponymum sa d’alej člení na 2.1.1. kozmonymum s významom vlastné meno neživého prírodného objektu a javu nachádzajúceho sa mimo Zeme a 2.1.2. geonymum/geo(topo)nymum/zemepisné meno $\mathrm{s}$ významom vlastné meno neživého prírodného objektu a javu nachádzajúceho sa na Zemi a toho človekom vytvoreného objektu na Zemi, ktorý je v krajine pevne fixovaný.

Geonymum sa následne rozčleňuje na 2.1.2.1. choronymum s významom vlastné meno väčšieho obývaného alebo neobývaného prírodného alebo správneho celku z hl'adiska horizontálneho členenia, 2.1.2.2. ojkonymum, osadný/miestny názov 
s významom vlastné meno obývaného miesta a to aj pustého a zaniknutého, 2.1.2.3. anojkonymum s významom vlastné meno neživého prírodného objektu a javu na Zemi a toho človekom vytvoreného objektu na Zemi, ktorý nie je určený na bývanie a je v krajine pevne fixovaný.

Anojkonymum je nadradeným termínom pre hydronymum/vodný názov s významom vlastné meno vody, oronymum/terénny názov s významom vlastné meno tvaru vertikálnej členitosti povrchu zemského aj morského dna (v rámci oronyma funguje aj speleonymum ako vlastné meno jaskyne), chotárny názov s významom vlastné meno zoskupenia pozemkov alebo jednotlivého pozemku, hodonymum s významom vlastné meno dopravnej cesty a vlastné meno jednotlivého neživého objektu a javu, ktorý nie je určený na obývanie a je v krajine pevne fixovaný.

Chrématonymum sa d'alej terminologicky nečlení.

V abionymickej časti je spolu 18 termímov (15 terminologických pojmov).

Podrobnejšie sme sa touto problematikou na základe dostupnej literatúry zaoberali v štúdii K vývinu, vzniku a d’alšiemu profilovaniu slovenskej onomastickej terminológie (Odaloš 2017).

\subsection{Princípy výstavby onomastickej terminológie}

Základná sústava terminológie bola vybudovaná na princípoch výstavby onomastickej terminológie. Princíp sa chápe v Krátkom slovníku slovenského jazyka (d’alej KSSJ) (2003: 585) ako 1. všeobecná základná zákonitost’, 2. základná zásada, resp. zásada je v KSSJ (2003: 923) predstavená ako spoločensky/individuálne ustálený názor na konanie. Ak potom princíp chápeme ako základný názor na konanie, tak v Základnej sústave terminológie sú uplatnené nasledovné princípy.

V časti A, ktorá obsahovala onomastické termíny podl'a objektov/javov, sa uplatňoval princíp terminologickej hierarchizácie. Princíp terminologickej hi e rarchizác i e na základe pojmovej špecifikácie bol podnetom na vytvorenie sústavy podradených a nadradených termínov. Centrálnym termínom je v sústave slovanskej a slovenskej onomastickej terminológie termín onymum, ktorý sa špecifikuje podradenými termínmi bionymum a abionymum.

Spolu s princípom terminologickej hierarchizácie spoluvytvára v časti A Základnú sústavu terminológie aj princíp významovej diferenciácie. Ak princíp terminologickej hierarchizácie vytvára terminologický strom, na vrchole ktorého sa nachádza najvšeobecnejší termín a jednotlivé vetvy vytvárajú špecifikujúce termíny, tak princíp významovej diferenciácie zabezpečuje sémantické odlíšenie pojmov na vertikálnej a horizontálnej rovine terminológie. Na vertikálnej úrovni vznikajú termíny, ktoré diferencujú terminológiu na nerovnakej úrovni abstrakcie, napr. bionymum — antroponymum — priezvisko alebo abionymum — toponymum — geonymum — anojkonymum — hydronymum. Na horizontálnej úrovni sa vytvárajú termíny, ktoré odlišujú terminológiu na rovnakej úrovni abstrakcie. 
V časti B, ktorá obsahovala termíny opisu a spracovania vlastných mien, dominoval princíp tematickej organizácie, pretože pri všeobecných onomastických termínoch boli vyprofilované skupiny vznik a vývoj vlastných mien, vlastné mená z hl’adiska obsahu, vlastné mená z hl'adiska formy, sústavy vlastných mien a ich fungovanie, jazykové zvláštnosti vlastných mien (odchýlky od apelatívnej sústavy jazyka), metodika a technika onomastiky, resp. aj pri opise a spracovaní bioným a abioným sa uplatňovala podobná tematická profilácia, napr. antroponomastické termíny sa členili na skupiny vznik a vývin antroponým, antroponymá z hl'adiska formy, antroponymické sústavy a ich fungovanie, metodika a technika antroponomastiky, príp. termíny vzt’ahujúce sa na osobné mená sa delili do skupín osobné mená z hl'adiska obsahu a sústavy osobných mien a ich fungovanie.

V d’alších onomastických sústavách sú uplatnené nasledujúce princípy.

Svobodovo triedenie (1960) na 1. vlastné mená všeobecne, 2. vlastné mená miest, 3. vlastné mená vecí (okrem miest), 4. vlastné mená živých tvorov vzniklo využitím princípov tematickej organizácie a terminologickej hierarchizácie a na základe používania terminológie hlavne v domácej podobe môžeme hovorit' aj o využití princípu významovej diferenciácie.

$\breve{S}$ milau erovo triedenie oným (1976: 109) na toponymá (1.-6. skupina oným), mená živých bytostí (7. skupina) a chrématonymá (8.-9. skupina) je vytvorené na základe princípu terminologickej hierarchizácie.

Superanskej triedenie oným (1973) na skupinu mien živých bytostí a bytostí chápaných ako živé, na skupinu mien neživých objektov a na skupinu vlastných mien komplexných objektov je utvorené tiež na princípoch terminologickej hierarchizácie a významovej diferenciácie.

Triedenie N. V. Podol'skej (1978) na reálonymá (vlastné mená reálne existujúcich objektov) a mýtonymá (vlastné mená reálne neexistujúceho objektu) je tiež utvorené na princípoch terminologickej hierarchizácie a významovej diferenciácie.

Onymá predstavené na we bovej stránke Ikosu (List of Key Onomastic Terms 2010) sú usporiadané na základe princípu formálnej špecifikácie (abecedné usporiadanie) a významovej diferenciácie, pretože onymá sú zoradené abecedne vždy s uvedením významu konkrétneho onyma.

\subsection{Vlastnosti onomastických termínov}

Základná sústava terminológie obsahuje 222 termínov, ktoré boli usporiadané na princípoch terminologickej hierarchizácie, významovej diferenciácie a tematickej organizácie.

Termíny a terminológia sa používajú v odbornej komunikácii v náučnom štýle, aby predkladané vedecké texty boli zrozumitel'né, t. j. aby mali presný význam, ktorý môžu odborníci dešifrovat' na základe terminológie. Termínom sa pripisujú 
viaceré vlastnosti, napr. podl’a B. Poštolkovej, M. Roudného a A. Tejnora (1983) sú to ustálenost', systémovost', medzinárodnost', priezračnost', nosnost', nocionálnost', jednomennost', jednoznačnost', ústrojnost', úkonnost', podl'a I. Masára (1991, 2000) spisovnost' (ustálenost', ústrojnost', funkčnost'), motivačnost'/motivačná priezračnost', systémovost', jednoznačnost', presnost', denotatívnost'.

K základným požiadavkám na termíny patrí systémovost' a ustálenost'.

Sys té movost' termínu sa chápe ako skutočnost', že termín patrí do systému terminológie konkrétneho vedného odboru. Systémovost' onomastickej terminológie bola vytvorená na základe klasifikačného kritéria čast' — celok, ked’ sa onymum člení na bionymum a abionymum.

Systémovost' sa v onomastickej terminológii posilňuje používaním časti-onymum na označenie termínov pre jednotlivé druhy vlastných mien, napr. antroponymum, toponymum, chrématonymum a pod., časti -onomastika na označenie vedy pre ich skúmanie, napr. antroponomastika, toponomastika, ojkonomastika, hydronomastika, časti -onymia na pomenovanie istého súhrnu vlastných mien, napr. antroponymia, toponymia, ojkonymia, hydronymia, časti -onomastikon na súpis vlastných mien, napr. onomastikon, toponomastikon, ojkonomastikon, hydronomastikon, oronomastikon. Systémovost' sa zabezpečuje nielen stanovením rozsahu odboru, vymedzením súboru pojmov, určením klasifikačných kritérií a usporiadaním pojmov s ich definíciami, ale aj používaním istých jazykových prostriedkov pre pojmy určitého charakteru.

Systémovost' má výrazné postavenie v procese tvorby terminológie, resp. v procese modifikácie terminológie/sústavy terminológie, ak dlhú dobu po schválení terminológie sa neuskutočnila jej aktualizácia.

Ustálenost' termínu vyjadruje, že terminológia je schválená a v odbornej praxi aj používaná. Základná jazykovedná terminológia (d’alej ZJT) (1952) zhrnula a ustálila gramatické termíny, ktoré boli potrebné pri vedeckej jazykovednej práci a pri vyučovaní slovenského jazyka a cudzích jazykov. Terminológia vlastných mien sa nachádzala $\mathrm{v}$ časti o náuke o slove a obsahovala tieto termíny: vlastné podstatné meno/proprium, národné podstatné meno, obyvatel'ské podstatné meno, priezvisko, prezývka/živé meno, osobné meno/krstné meno, miestne podstatné meno, pomiestne podstatné meno (ZJT 1952: 16). V nadväznosti aj na tento dokument vznikla Základná sústava terminológie (1973) a jej modifikácia Osnoven system i terminologija na slovenskata onomastika (1983). Ustálenost' terminológie sa preto viaže na istý časový východiskový bod, v prípade sústavy slovenskej a slovanskej onomastickej terminológie sú to roky 1973 a 1983, a odborný dokument, ktorého dodržiavanie zabezpečuje porozumenie si odborníkov. 


\section{DYNAMIKA ONOMASTICKEJ TERMINOLÓGIE}

Pod dynamikou onomastickej terminológie chápeme zmapovanie pohybov, ktoré sa uskutočnili v slovenskej onomastickej terminológii aj vo vzt’ahu $\mathrm{k}$ sústave slovanskej onomastickej terminológie po roku 1973.

Pri profilovaní Základnej sústavy terminológie bola rešpektovaná požiadavka J. Svobodu nepret’ažovat' terminológiu zvláštnymi názvami pre všetky druhy objektov (Základná sústava terminológie 1973: 10). To znamená, že sa zvažovalo zaradenie toho-ktorého vlastného mena do terminológie. Na druhej strane L. Olivová-Nezbedová a L. Oliva (Základná sústava terminológie 1973: 19) zdôrazňujú, že Základná sústava terminológie je otvorená sústava a jej autori rátajú s tým, že s d’alším rozvojom onomastiky ju bude treba doplńă'.

V d’alšej časti sa sústredíme na vybrané otázky či problémy dynamiky onomastickej terminológie.

\subsection{Terminologická diferenciácia chrématoným}

V Základnej sústave terminológie (1973: 22) sa chrématonymá d’alej terminologicky nečlenia, no za ich definíciou ako vlastné mená l’udského výtvoru, ktorý nie je pevne fixovaný v prírode, sa d’alej špecifikujú na a) vlastné mená spoločenského javu (sviatok atd'.), b) vlastné meno spoločenskej inštitúcie, c) vlastné meno predmetu a výrobku (jednotlivého ako umelecké dielo, zvon, lod’ a pod. alebo sériového ako auto, motocykel, písací stroj, kozmetický výrobok a pod.). Špecifikácia v triadickej podobe nadväzuje na Šmilauerovo dichotomické triedenie chrématoným (1976: 111) prednesené v roku 1972, na 1. pojmy a inštitúcie (1a. časové pojmy, 1b. deje, 1c. inštitúcie politické, správne, hospodárske, školské, kultúrne) a 2. veci (2a. jednotlivé veci (umelecké diela; technické diela; dopravné prostriedky; šlachtitel'ské druhy; odevy, obuv; jedlo, pitie, fajčenie; ozdoby, kozmetika), 2b. sériové výrobky).

Najnaliehavejšie sa preto, vzhl'adom na vývoj onymie, ukazuje potreba vytvorit' terminológiu v rámci chrématonymie.

M. Majtán (1989) vychádza z členenia v Základnej sústave terminológie významovo, pretože preberá alebo modifikuje pomenovania jednotlivých okruhov chrématonymie, resp. aj kompozične, pretože tiež pracuje s troma okruhmi chrématoným. M. Majtán (1989) člení chrématonymá na: vlastné mená spoločenského javu, vlastné mená spoločenskej inštitúcie a vlastné mená výsledku spoločenskej činnosti.

Vlastné mená spoločenského javu (názov okruhu chrématonymie má identický názov ako v Základnej sústave terminológie): 1a) vlastné meno časového javu - chrononymum, 1b) vlastné meno spoločenskej udalosti/akcie - akcionymum, 1c) vlastné meno spoločenského ocenenia - faleronymum. M. Majtán 
pri vlastných menách spoločenského javu rozširuje počet uvádzaných podskupín v porovnaní so Základnou sústavou terminológie z jednej na tri, používa na označenie každej podskupiny samostatný názov v podobe jednoslovného termínu a uvádza väčší počet príkladov, ktoré patria do tejto podskupiny.

Vlastné meno spoločenskej inštitúcie (inštitúcionymum) (názov okruhu chrématonymie má identický názov ako v Základnej sústave terminológie) člení tematicky pod vplyvom klasifikácie V. Šmilauera (1976: 11) na vlastné meno politickej, správnej, hospodárskej, školskej, kultúrne a cirkevnej organizácie bez uvedenia konkrétnych jednotlivých termínov. J. Horecký (1994: 76) navrhol používat' logonymum na pomenovanie inštitúcie a logonomastiku na označenie náuky o pomenovaní inštitúcií a využívaní jazykových prvkov v logu. Logonymá skúmala aj M. Imrichová (2002). P. Odaloš (2015: 467) navrhol členit' vlastné mená spoločenskej inštitúcie na inštitúcionymá v zmysle štátnych zariadení a na firmonymá v zmysle vlastných mien podnikatel'ských (súkromných) subjektov.

Vlastné meno výsledku spoločenskej činnosti je ako pomenovanie rozšírením pomenovania vlastné meno predmetu a výrobku zo Základnej sústavy terminológie. Tu možno položit’ otázku, či aj predchádzajúce dve podskupiny nie sú výsledkom spoločenskej činnosti, či nie je rozšírený názov spoločenskej činnosti vel'mi všeobecný. Uvedenú podskupinu delí M. Majtán na dokumentonymum/aktonymum (vlastné meno diplomatického aktu), ideonymum (vlastné meno vedeckého, publicistického a umeleckého diela a jeho časti), unikátonymum (vlastné meno jedinečného výrobku/predmetu), porejonymum (vlastné meno dopravného spoja), pragmatonymum (vlastné meno výrobného typu). V rámci ideoným umeleckého charakteru sa objavujú jednotlivé termíny na pomenovanie rôznych výsledkov umeleckej činnosti, napr. literáronymum v zmysle vlastných mien literárnych diel, pinakonymum v zmysle vlastných mien výtvarných diel (viacej Odaloš 2003, 2015: 470), resp. muzikonymum v zmysle vlastného mena hudobného diela (Žigo 2010).

Predstavené terminologické inovácie sú výsledkom vedeckého výskumu od konca 80. rokov 20. storočia až do súčasnosti a poukazujú na deklarovanú skutočnost', že práve vedecký výskum chrématonymie je výrazným akcelerátorom dynamiky celej onymie (Odaloš 2011: 347).

\subsection{Urbanonymá versus hodonymá}

Základná sústava terminológie obsahuje termín hodonymum spolu s termínmi hydronymum, oronymum, chotárny názov a vlastné meno jednotlivého neživého prírodného objektu a javu a toho človekom vytvoreného objektu, ktorý nie je určený na obývanie a je v krajine pevne fixovaný $\mathrm{v}$ rámci anojkoným čiže vlastných mien neživých prírodných objektov a javov na Zemi a tých človekom vytvorených objektov na Zemi, ktoré nie sú určené na bývanie a sú v krajine pevne fixované. 
Hodonymum je v Základnej sústave terminológie (1973: 60) definované ako vlastné meno dopravnej cesty (ulice, námestia, nábrežia, móla, dial'nice, cesty, cestičky, priechodu, tunela, brodu, mosta, lávky, železnice, lanovky a pod.). J. Bauko používa termín orohodonymum (2009: 9) na pomenovanie horolezeckých (skalolezeckých) ciest.

N. V. Pod'ol'skaja v Slovníku ruskej onomastickej terminológie (1978) pojem vlastného mena dopravnej cesty rozčlenila medzi dva termíny, pretože $\mathrm{k}$ toponymám zaradila dromonymá $\mathrm{v}$ zmysle vlastných mien dopravnej tepny a aj urbanonymá ako vlastné mená vnútromestských objektov, ktoré ešte rozčlenila na agoronymá (vlastné mená námestia), hodonymá (vlastné mená ulíc) a mestské choronymá v zmysle vlastných mien mestskej štvrte. Hodonymum N. V. Podol'skaja chápe užšie, kým v Základnej sústave terminológie je vysvetlené širšie.

M. Majtán (1988: 8) v súlade $\mathrm{s}$ N. V. Podol'skou chápe urbanonymá ako názvy mestskej toponymie, teda názvy častí sídel mestského typu: a) názvy mestských obvodov, urbanistických obvodov, sídlisk, b) názvy ulíc, námestí a iných verejných priestranstiev, c) názvy jednotlivých budov a stavieb. Za vhodné považuje tiež rozlišovanie názvov ulíc (hodonymá) a názvov ciest pozemnej, vodnej a vzdušnej dopravy (dromonymá).

$\mathrm{K}$ chápaniu hodonyma v Základnej sústave terminológie $\mathrm{N}$. V. Podol'skaja ponúkla dva termíny dromonymum a urbanonymum (členené na agoronymum, hodonymum a mestské choronymum) a M. Majtán urbanonymum a dromonymum. U obidvoch lingvistov došlo k rozčleneniu pojmu dopravnej cesty na pojem dopravnej cesty a pojem vnútromestskej/mestskej toponymie (pozri aj L. Zgusta 1995).

\section{3. Ďalšie nové onomastické termíny}

Prirodzeným vývojom onomastiky sa objavujú viaceré d’alšie nové jednoslovné termíny, napr. skionymum s významom názov lyžiarskeho strediska, resp. názov svahu (Wachtarczyková 2012), socioonymum s významom názov spoločenskej skupiny (Wachtarczyková 2015) a pod.

\section{ONOMASTICKÉ ŠKOLY A TERMINOLÓGIA}

V jazykovede sa lingvistické školy pomenúvajú podl’a hlavného predstavitel’a, podl'a miesta existencie školy, podl’a predmetu záujmu školy a na základe etnického princípu, častokrát sa predstavené kritériá kombinujú a do názvu školy sa dostane viacero kritérií. 
3.1. Onomastické školy podl'a etnického princípu/podla miesta existencie školy/podla hlavného predstavitel'a

Onomastické školy uvádzame v abecednom poradí.

Česká onomastická škola

V západoslovanskej onomastike sa pomenovanie onomastická škola objavuje v 80. rokoch 20. storočia, ked' I. Lutterer (1975) napísal štúdiu o českej onomastickej škole. Paralelne s označením česká onomastická škola sa používa aj synonymný termín Šmilauerova škola, ktorého autor textu považuje za zakladatel’a českej onomastickej školy. Aby vznikla onomastická škola, sú potrební podl’a I. Lutterera a) zakladatel'ská osobnost' učitel'a, b) spol'ahlivá teoreticko-metodologická základňa práce, c) žiaci, ktorí pod učitel’ovým vedením sú schopní pracovat' jedným smerom a k jednému ciel'u. Vznik českej onomastickej školy podmienili vonkajšie a vnútorné podmienky. Vonkajšie podmienky súviseli s potrebou vzniku onomastickej terminológie a vytvorením Medzinárodnej komisie pre slovanskú onomastiku v októbri roku 1959 v Krakove. Vnútorné podmienky boli determinované dokončením Profousovho diela o toponymii Čiech (1957) a možnost'ou na základe typologického rozboru českej toponymie dôjst' $k$ poznatku o vývoji osídl'ovania Čiech, vytvorením onomastickej komisie pri Československom komitéte slavistov na rozhraní rokov 1958-1959 a premenou Místopisné komise ČSAV na organizačnú a pracovnú základňu českej onomastiky spojenú aj s vydávaním „Zpravodaja Místopisné komise ČSAV“ od januára 1960.

M. Harvalík (2012) v nadväznosti na štúdiu I. Lutterera predstavuje chápanie onomastiky v českej onomastickej škole ako náuky o vlastných menách, ktoré je poňaté $\mathrm{v}$ zmysle samostatnej jazykovednej disciplíny s úzkou spoluprácou lingvistov s predstavitel'mi rôznych odborov, predovšetkým s historikmi, archivármi a geografmi, ale aj so sociológmi, psychológmi, etnografmi, archeológmi, prírodovedcami a právnikmi. Česká onomastika vo svojich teoretických a metodologických princípoch rozvíja onomastickú teóriu v nadväznosti na tradície štrukturalizmu Pražského lingvistického krúžku s dôrazom na funkčné hl'adisko a systémové chápanie vlastných mien ako štruktúrovaného celku. M. Harvalík prepája českú onomastickú školu s českou onomastikou a jej výsledkami, pretože d’alej spomína ojkonomastické, anojkonomastické, antroponomastické, chrématonomastické a literáronomastické práce $\mathrm{v}$ českej onomastike.

\section{Lipská onomastická škola}

Lipská onomastická škola sa zameriava na osvetl’ovanie sídliskových dejín oblasti na základe rekonštrukcie starých lužickosrbských miestnych názov. Vedúcou osobnost'ou školy je Ernst Eichler, ktorý vypracoval integračný model zložitého medzijazykového preberania na západoslovansko-nemeckom kontaktovom území. 
E. Eichler rozpracoval metódu rekurzu, ktorá sa zameriava na zistenie predpokladanej formy vlastného mena $v$ jeho možnej modelovej podobe. Tento model sa stal základným princípom onomastických syntéz a atlasového spracovania typov starolužických miestnych názvov (Blanár 2008b).

Pol'ská onomastická škola

E. Rzetelelska-Feleszko (2003) pracuje s termínom polská onomastická škola, ktorý d’alej špecifikuje ako pol'ské onomastické školy: onomastická škola Witolda Taszyckiego, onomastická škola Stanisława Rosponda a onomastická škola Huberta Górnowicza. Onomastické školy charakterizuje nasledovne.

Onomastická škola Witolda Taszyckiego v L'vove a v Krakove je založená na práci Słowiańske nazwy miejscowe. Ustalenie podziatu (1946) a na klasifikácii miestnych názvov prostredníctvom sémantického kritéria. Taszyckiego klasifikácia sa zhoduje v značnej miere s klasifikáciou osídlenia historikov, ktorí pracovali s patronymickými, služobnými či rodovými názvami. Kategória sémantických miestnych názvov sa spájala s určitou slovotvornou štruktúrou, napr. patronymické názvy fungovali s príponou -ice (Sulisławice), služobné/služobnícke plurálové názvy s príponou -niki (Lagiewniki) a -ary (Psary), rodové názvy sa rovnali plurálovým formám osadných názvov, privlastňovacie názvy s príponou *-jb (Bydgoszcz, *Bydgost). Taszyckiego klasifikáciu rozširujúco modifikuje H. Borek používaním termínu nazwy relacyjne (1988) a termínu nazwotwórstwo (1984).

Onomastická škola Stanisława Rosponda vo Wroclave a v Opole vychádzala zo záujmu o štruktúru a slovotvorbu názvov a priviedla autora k štruktúrno-gramatickej klasifikácii slovanských geografických názvov. Hlavným kritériom pri tejto klasifikácii je morfologický základ názvov, ktoré sa členia na 1. primárne názvy spojené s etymologicko-lexikálnym kritériom, 2. sekundárne názvy spojené tiež s funkciou sufixov a 3. kompozitné názvy. So S. Rospondom je $\mathrm{v}$ pol'skej onomastike spojený prechod $\mathrm{k}$ štrukturalizmu pri analýze slovnej zásoby a do onomastiky sa následne dostala terminológia ako onomastická stratigrafia, toponomastický systém, jednomenný/dvojmenný systém, jednoelementový/dvojelementový systém, modely názvov a iné. Viaceré z termínov sa dostali aj do Základnej sústavy terminológie onomastiky. Rospondova klasifikácia mala vplyv na výskum štruktúry miestnych názvov so sufixom *-bn- (Brzeźno), -ov/-ev (Budowo, Budów), -in (Gogolin), -izna (Celechowizna), -ical-nica (Golica, Dobropolnica), na osobné dvojčlenné názvy aj názvy so sufixom -eh či na výskum toponomických štruktúr.

Onomastická škola Huberta Górnowicza v Gdaňsku súvisela s prenesením metódy E. Eichlera z lipskej školy. Metóda bola založená na zdokumentovaní a analyzovaní všetkých druhov lokálnych toponymov (názvov osád, terénnych názvov, názvov riek, jazier) na malom priestore (okres). Pri opise a analýze materiálov bola použitá sémantická aj štruktúrno-gramatická metóda. 
Pri sumarizácii škôl na nominatívnej úrovni pracuje autorka textu s termínmi západoslovanská a východoslovanská onomastická škola. Charakterizuje len prvú menovanú školu.

Západoslovanská onomastická škola vzniká na základe prenikania metód, chápania problematiky a formulovania spoločných výskumných ciel'ov. Týka sa to štruktúrnej interpretácie názvov aj etymologicko-sémantickej analýzy. Výskumný tím R. Šrámek, E. Eichler, H. Borek, M. Majtán vypracoval v roku 1988 jednotnú schému štruktúrneho opisu aj klasifikácie miestnych názvov v západných slovanských jazykoch.

Slovenská onomastická škola

V. Blanár (2008b) slovenskú onomastickú školu chápe ako súbor rozličných pracovných aktivít a rozvíjanie teoretickej základne.

Za pracovné aktivity považuje budovanie materiálových korpusov, formulovanie dotazníkov a terénnu explorátorskú prácu. Uvedené aktivity spája s výskumom živých osobných mien (existuje súbor 2500000 názvov v B. Bystrici), toponymie (250 000 terénnych názvov v Bratislave) a hydronymie (materiál sa nachádza v lexikografických dielach).

Teoretickú základňu predstavujú myšlienky V. Blanára, ktoré publikoval vo svojich prácach (1996, 2008a a iné). Vlastné mená majú lingvistický a onomastický status a ich spoločnou integratívnou funkciou je spoločensky podmienená identifikácia a diferenciácia jedinca $v$ rámci daného druhu. Vlastné meno ako onymický znak má obsahovú a formálnu stránku, pričom znaky v jednotlivých triedach vytvárajú systém. Onymický systém má svoju dimenziu priestoru, času a frekvenciu. V priestore sa onymá viažu na objekty pri toponymách v rámci zemepisných areálov, pri antroponymách sociálnymi a pri chrématonymách ekonomickými vzt’ahmi. V čase sa onymá aj ich sústavy menia, napr. jednomenná sústava sa zmenila na dvojmennú, pričom sa zrealizovala vnútorná prestavba funkčných členov.

V podmienkach neúradného súkromného komunikačného styku funguje sústava živých osobných mien. Jednotlivé triedy osobných mien (krstné mená, priezviská, individuálne charakteristiky, prímená, živé osobné mená, mená domov) predstavujú mikrosystémy s nerovnakou onymickou platnost'ou a onymickou sémantikou. V triedach sa konkrétne mená skladajú z funkčných členov. Funkčné členy sú základné prvky antroponymických podsystémov. Ked' funkčné členy zaznamenávame $\mathrm{v}$ rámci mena, tak na základe modelových abstrakcií vytvárame modely. Opísanie pomenovacích modelov cez metajazyk umožňuje spracúvat' a klasifikovat' onymické modely štatistickými a areálovými metódami. Problematika modelov, funkčných členov a modelovania patrí medzi charakteristické prínosy slovenskej onomastiky do metodológie modernej onomastiky (pozri aj Odaloš 2012, tiež čast' 3.2.). 
Blanárove termíny sa dostali v Základnej sústave terminógie onomastiky do hesiel neúradné/živé vlastné meno a živé rodinné meno/meno podl’a domu.

\subsection{Onomastická škola podl'a predmetu záujmu}

Československá škola onomastického modelovania je produktom systematickej výskumnej práce slovenskej a českej onomastiky v 60. a 70. rokoch 20. storočia (Odaloš 2012).

Škola vychádza z koncepcií teórií vlastných mien V. Blanára a R. Šrámka. V. Blanár (1996: 132-133, predtým 1972: 7-50) považuje modely a ich zložky za systémovotvorné prvky onomastickej sústavy. V. Blanár profiloval modely v antroponomastike v rámci živých osobných mien, R. Šrámek (1999) a J. Pleskalová (1992) v toponomastike $\mathrm{v}$ rámci ojkoným a anojkoným, P. Odaloš v chrématonomastike $\mathrm{v}$ rámci chrématoným (2015).

Ciel'om modelového prístupu je zobrazenie propria ako prvku a typu v rámci určitého onomastického systému na základe dohodnutých symbolov. V. Blanár (1996: 168-171) a P. Odaloš (2015: 464-472) zostavujú model na základe antroponomastických a chrématonomastických príznakov. R. Šrámek (1999: 37) pracuje v rámci ojkonomastiky a J. Pleskalová (1992) v anojkonomastike so všeobecnými sémantickými kategóriami. V. Blanár používa termín obsahový model, R. Šrámek vztahový model a P. Odaloš model A1.

Modelovanie v onomastike je špecifická činnost', ktorej výsledky je potrebné pomenovat' novými onomastickými termínmi. Vyformované modely $\mathrm{v}$ onomastike na úrovni obsahu sa pomenúvajú termínmi obsahový model (V. Blanár), vztahový model (R. Šrámek), motivačný model (J. Pleskalová), model A1 (P. Odaloš). V. Blanár (1996: 60) zastrešuje obsahový, motivačný a slovotvorný model termínom pomenovací model. R. Šrámek (1999: 35-36) používa tiež termín model propriálne pomenovacieho aktu a slovotvorný/názvotvorný model.

Jedným z výsledkov československej školy onomastického modelovania okrem modelovania onymie je aj vznik a používanie špecifickej terminológie.

\subsection{Chápanie onomastických škôl}

V predstavených chápaniach onomastických škôl nachádzame rozličné uhly pohl'adu na uvedenú problematiku.

Označenie onomastickej školy podl'a hlavného predstavitel'a je prirodzeným pomenovaním školy, napr. Šmilauerova škola, onomastická škola Witolda Taszyckiego, onomastická škola Stanisłava Rosponda, onomastická škola Huberta Grónowicza. Ide bud' o zakladatel'a vedného odboru v tej-ktorej krajine alebo o predstavitel'a, ktorý svojimi prácami a špecifickým prístupom vybudoval nové pracovisko. 
Označenie onomastickej školy podla etnického princípu pomenúva školu v určitej krajine, väčšinou menšej alebo vo väčšej krajine v prvej etape rozvoja vednej disciplíny, pretože vo väššej krajine sa postupne profilujú školy na viacerých miestach v súvislosti s rozvojom vedného odboru.

Označenie onomastickej školy podla miesta jej existencie pomenúva školu, ktorá sa nachádza v určitom centre, napr. lipská onomastická škola.

Označenie onomastickej školy podl’a predmetu záujmu školy dostáva väčšinou označenie podl’a najvýznamnejšieho vedeckého výsledku školy, napr. československá škola onomastického modelovania.

\subsection{Onomastická škola a jej vzt’ah k terminológii}

Každá onomastická škola prichádza k novým vedeckým výsledkom. V súvislosti s vedeckými výsledkami použivajú jej predstavitelia novú terminológiu na pomenovanie nových vedeckých pojmov, napr. metóda malých typov (V. Šmilauer), metóda rekurzu (E. Eichler, R. Šrámek), teória makrotypov (S. Rospond), paradigma funkčnej onomastiky (R. Šrámek), sémantická klasifikácia oným/miestnych názvov (W. Taszycki), štruktúrno-gramatická klasifikácia geografických názvov (S. Rospond), obsahový model (V. Blanár), vzt’ahový model (R. Šrámek), model A1 (P. Odaloš), pomenovací model (V. Blanár) a pod.

V. Blanár (2002: 84-85) upozorňuje na termíny fungujúce v onomastike (mohli by sme povedat' aj v slovenskej onomastickej škole), ktoré sa nenachádzajú v Základnej sústave terminológie a bolo by ich tam potrebné doplnit'. Sú to termíny: špecifické onomastické črty (prvky), špecifikum onomastiky, lingvistický a onomastický status vlastného mena, onymická (propriálna) sémantika (designácia), generické a diferenčné onymické priznaky, pomenovací model: obsahový, motivačný, slovotvorný, identifikácialdiferenciácia vlastného mena, referenčná identifikácia, presupozičná identifikácia, dimenzia onymického systému, prierezový antroponymický systém, sociolingvistický aspekt onomastiky, apelatívny a propriálny kontext vlastného mena.

\section{ZÁVEREČNÁ POZNÁMKA}

4.1. Predstavený analyticko-prehl’adový prístup poukázal na základnú úlohu sústavy slovenskej a slovanskej onomastickej terminológie a na vybrané prípady dynamického vývoja $\mathrm{v}$ onomastickej terminológii vrátane prístupov západoslovanských onomastických škôl.

4.2. Z predstaveného analyticko-prehl'adového prístupu vyplynula potreba zaoberat' sa terminológiou vo vzt'ahu $\mathrm{k}$ tradícii sústavy onomastickej terminológii aj vo vzt’ahu k dynamike terminológie aj terminológii onomastických škôl so zámerom 
a) zhodnotit' nosnost' sústavy onomastickej terminológie, slovenskej aj slovanskej onomastickej terminológie, b) analyzovat' obdobie po roku 1973/1983 až do súčasnosti z hl'adiska vývoja terminológie, c) modifikovat' sústavu slovenskej aj slovanskej onomastickej terminológie na základe dohody v Terminologickej subkomisii Komisie slovanskej onomastiky pri Medzinárodnom komitéte slavistov.

\section{LITERATÚRA}

Bauko J. 2009: Paralely medzi názvami skál a horolezeckých ciest, [v:] M. Ivanová, M. Ološtiak (red.), Varia XVIII. Zborník abstraktov z XVIII. kolokvia mladých jazykovedcov. Prě̌ov-Kokošovce-Sigord 3.-5. 12. 2008, Filozofická fakulta Prešovskej univerzity v Prešove-Slovenská jazykovedná spoločnost' pri SAV, Prešov, s. 9-10.

Blanár V. 1972: Problematika výskumu živých mien, [v:] V. Blanár (red.), „Acta Facultatis Paedagogicae Banská Bystrica“: Zbornik materiálov z III. slovenskej onomastickej konferencie 4. XI.-6. XI. 1970, Pedagogická fakulta, Banská Bystrica, s. 7-50.

Blanár V. 1996: Teória vlastného mena (Status, organizácia a fungovanie v spoločenskej komunikácii), Veda, Bratislava.

Blanár V. 2002: Onomastická terminológia, [v:] E. Rzetelska-Feleszko, A. Cieślikowa, J. Duma (red.), Stowiańska onomastyka. Encyklopedia, t. I, Tow. Naukowe Warszawskie, Warszawa-Kraków, s. $84-85$.

Blanár V. 2008a: Vlastné meno vo svetle teoretickej onomastiky, Matica slovenská, Bratislava.

Blanár V. 2008b: Slovenská onomastická škola, [v:] P. Žeňuch (red.), XIV. medzinárodný zjazd slavistov v Ochride. Príspevky slovenských slavistov, Slovenský komitét slavistov-Slavistický ústav Jána Stanislava SAV, Bratislava, s. 41-49.

Borek H. 1984: Z problematyki nazwotwórstwa toponimicznego, „Zeszyty Naukowe WSP w Opolu, Językoznawstwo" IX, Opole.

Borek H. 1988: Nazwy relacyjne w toponimii, [v:] K. Zierhoffer (red.), V Ogólnopolska Konferencja Onomastyczna, Poznań 3-5 września 1985, Ksiega referatów, Wyd. Naukowe UAM, Poznań, s. 43-51.

Harvalík M. 2012: Česká onomastická škola po 36 rokoch, [v:] S. Čmějrková, J. Hoffmannová, J. Klímová (red.), Čěstina v pohledu synchronním a diachronním. Stoleté kořeny Ústavu pro jazyk český, Univerzita Karlova, Praha, s. 495-499.

Horecký J. 1994: Logonomastika ako onomastická disciplína, [v:] E. Krošláková (red.), 11. slovenská onomastická konferencia. Nitra 19.-20. mája 1994. Zbornik referátov, Jazykovedný ústav L’udovíta Štúra SAV-Vysoká škola pedagogická, Bratislava-Nitra, s. 76-80.

Imrichová M. 2002: Logonymá v systéme slovenčiny, Prešovská univerzita v Prešove — Fakulta humanitných a prírodných vied, Prešov.

Kačala J., Pisárčiková M. (red.) 2003: Krátky slovník slovenského jazyka, Veda, Bratislava [= KSSJ].

List of Key Onomastic Terms 2010: http://icosweb.net/drupal/sites/default/files/ICOS-Terms-en.pdf (dostupné 17. 11. 2016).

Lutterer I. 1975: Česká onomastická škola, „Zpravodaj místopisné komise ČSAV” 16, 1975, s. 15-21.

Majtán M. 1988: Onymia a urbanonymia, [v:] P. Žigo (red.), Urbanonymia. Zborník prednášok z 2. celoštátneho onomastického seminára, Modra-Piesky 8.-10. októbra 1986, Univerzita Komenského, Bratislava, s. 6-9.

Majtán M. 1989: Klasifikácia chrématonymie, [v:] R. Šrámek, L. Kuba (red.), Chrématonyma z hlediska teorie a praxe, Onomastická komise ČSAV, Ústí nad Labem, s. 7-13. 
Masár I. 1991: Príručka slovenskej terminológie, Veda, Bratislava.

Masár I. 2000: Ako pomenúvame. Kapitolky z terminologickej teórie a praxe, Slovenská jazyková spoločnost‘ pri SAV-Jazykovedný ústav Ludovíta Štúra SAV, Bratislava.

Odaloš P. 2003: Literáronymá v Ballekovej próze 60. rokov, [v:] P. Odaloš, J. Lomenčík (red.), Literárne tradicie Banskej Bystrice I. (60. roky 20. storočia). Zborník z vedeckej konferencie, Banská Bystrica 20. marca 2002, Pedagogická fakulta Univerzity Mateja Bela, Banská Bystrica, s. 43-57.

Odaloš P. 2011: Dynamika chrématonymie ako faktor dynamizácie onymie, [v:] M. Biolik, J. Duma (red.), Chrematonimia jako fenomen wspótczesności, Wyd. UWM, Olsztyn, s. 347-356.

Odaloš P. 2012: Kontinuita jednotlivého a všeobecného v onomastike, [v:] M. Ološtiak (red.), Jednotlivé a všeobecné v onomastike. 18. slovenská onomastická konferencia, Prešov 12.-14. septembra 2011, Filozofická fakulta Prešovskej univerzity, Prešov, s. 14-21.

Odaloš P. 2015: Modelovanie a modely chrématoným, [v:] I. Valentová (red.), 19. slovenská onomastická konferencia, Veda, Bratislava, s. 464-472.

Odaloš P. 2017: K vývinu, vzniku a d’alšiemu profilovaniu slovenskej onomastickej terminológie. [v:] R. Przybylska, W. Śliwiński (red.), Terminologia specjalistyczna w teorii i praktyce językoznawców stowiańskich, Wyd. UJ, Kraków, s. 277-294.

Osnoven system i terminologija na slovenskata onomastika. Osnovnaja sistema i terminologija slavjanskoj onomastiki. Grundsystem und Terminologie der slawischen Onomastik, GZ Goce Delčev, Skopje, 1983.

Pleskalová J. 1992: Tvořeni pomistnich jmen na Moravě a ve Slezsku, H \& H, Jinočany.

Podol'skaja N. V. 1978: Slovar' russkoj onomastičeskoj terminologii, Nauka, Moskva.

Poštolková B., Roudný M., Tejnor A. 1983: O české terminologii, Academie, Praha.

Rzetelska-Feleszko E. 2003: Specyfika polskich szkół onomastycznych. Zwiqzki (lub ich brak) z onomastykq innych krajów słowiańskich, [v:] R. Łobodzińska (red.), Przeszłość, teraźniejszość i przyszłość polskiej onomastyki, Wyd. Wrocławskiego Tow. Naukowego, Wrocław, s. 27-32.

Superanskaja A. V. 1973: Obščaja teoria imeni sobstvennogo, Moskva.

Svoboda J. 1960: K slovanské onomastické terminologii, „Zpravodaj Místopisné komise ČSAV” 1, s. $273-284$.

Svoboda J. a kol. 1973: Základni soustava a terminologie slovanské onomastiky, „Zpravodaj Místopisné komise ČSAV" 14, s. 1-280.

Šmilauer V. 1976: Tř́lění vlastních jmen. (Teze), [v:] M. Blicha, M. Majtán (red.), Slavistika. V. zasadnutie Medzinárodnej komisie pre slovanskú onomastiku a V. slovenská onomastická konferencia, Slovenské pedagogické nakladatel'stvo, Bratislava, s. 109-111.

Šrámek R. 1999: Úvod do obecné onomastiky, Masarykova univerzita, Brno.

Taszycki W. 1946: Stowiańske nazwy miejscowe. Ustalenie podziału, PAU, Kraków.

Wachtarczyková J. 2012: Povaha a podoba názvov lyžiarskych stredisk na Slovensku, [v:] M. Ološtiak (red.), Jednotlivé a všeobecné v onomastike. 18. slovenská onomastická konferencia, Filozofická fakulta Prešovskej univerzity, Prešov, s. 342-341.

Wachtarczyková J. 2015: Socionymá - pomenovania spoločenských skupin (na príklade názvov občianskych združení a sút’ažných dvojic), [v:] I. Valentová (red.), 19. slovenská onomastická konferencia, Veda, Bratislava, s. 478-497.

Základná jazykovedná terminológia, 1952: red. J. Horecký, Slovenská akad. vied a umení, Bratislava $[=\mathrm{ZJT}]$.

Zgusta L. 1995: Names and Their Study, [v:] E. Eichler, G. Hilty, H. Löffler, H. Steger, L. Zgusta (red.), Namenforschung. Ein internationaler Handbuch zur Onomastik, II, Walter de Gruyter, Berlin-New York, s. 1876-1890.

Žigo P. 2010: Budú v onomastike aj muzikonymá, „Slovenská reč“ 75, s. 270-277. 


\section{TRADITION AND DYNAMICS IN TERMINOLOGY AND TERMINOLOGY OF THE ONOMASTIC SCHOOLS}

\section{SUMMARY}

The aim of the article is to introduce the stimuli to the future development of the system of Slovak and Slavic onomastic terminology. The article is based on the tradition and dynamics of Slovak and Slavic terminology, including the terminology used by Slavic onomastic schools.

Key w ord s: onomastic terminology, terminology of the onomastic terminological schools 